\title{
Epidemiological factors associated with Toxoplasma gondii infection in postpartum women treated in the public healthcare system of Goiânia, State of Goiás, Brazil
}

\author{
Juliana Boaventura Avelar ${ }^{[1]}$, Marcos Gontijo da Silva ${ }^{[2]}$, Hanstter Hallison Alves Rezende ${ }^{[1]}$, \\ Heloisa Ribeiro Storchilo[1], Waldemar Naves do Amaral ${ }^{[3]}$, Isolina Rodrigues Xavier ${ }^{[3]}$, \\ Mariza Martins Avelino ${ }^{[3]}$ and Ana Maria de Castro ${ }^{[1]}$
}

\author{
[1]. Instituto de Patologia Tropical e Saúde Pública, Universidade Federal de Goiás, Goiânia, GO, Brasil. \\ [2]. Centro Universitário, UNIRG, Gurupi, TO, Brasil.
}

[3]. Hospital das Clínicas, Universidade Federal de Goiás, Goiânia, GO, Brasil.

\begin{abstract}
Introduction: Knowledge of the epidemiological profile and risk factors for Toxoplasma gondii infection among postpartum women is a relevant issue, because this protozoan can be vertically transmitted to the developing fetus, which can cause severe and debilitating disease. The aim of this study was to assess the risk factors associated with T. gondii infection in postpartum women in Goiânia, GO, Brazil. Methods: This cross-sectional study comprised 229 postpartum women, among whom 204 were chronically infected (IgG+/IgM-), and 25 were seronegative (IgG-/IgM-; control group). All the patients were asked to complete a form to provide sociodemographic, clinical, dietary, and cultural information. The data were analyzed to compare seropositivity and risk factors based on the odds ratio (OR) thereof. Results: The sociodemographic characteristics associated with the risk for toxoplasmosis were: education $\leq 8$ years [OR: 2.521 , confidence interval $(\mathrm{CI}): 1.01-6.301, \mathrm{p}=0.049$ ], and age $\geq 30$ years $(\mathrm{OR}$ : 4.090; CI: 1.180-14.112, $\mathrm{p}=0.023$ ). Clinical and behavioral characteristics related to eating raw and undercooked meat, were not found to be risk factors associated with a positive test for toxoplasmosis. Conclusions: Our findings concur with the results of other studies conducted in Brazil and abroad, where variables such as low levels of schooling, and advanced age ( $\geq 30$ years) are major risk factors for pregnant women to become infected with $T$. gondii.
\end{abstract}

Keywords: Toxoplasma gondii. Postpartum women. Diagnosis. Risk factors.

\section{INTRODUCTION}

Toxoplasma gondii is one of the main factors responsible for neonatal morbidity and mortality ${ }^{1}$. Knowledge about the factors responsible for the dissemination of $T$. gondii among postpartum women is important because, when acquired congenitally, this disease can trigger lesions with severe sequelae in newborns ${ }^{2,3}$.

Pregnant women in the chronic stage of $T$. gondii infection may experience worsening of the disease, ${ }^{4-6}$ or even become reinfected $^{7}$. The etiologic agent of toxoplasmosis can reach the placenta hematogenously, and can potentially infect the fetus and give rise to congenital toxoplasmosis ${ }^{8}$. This infection can kill the fetus, or cause changes that aggravate the health of surviving children'. Several clinical alterations such as seizures only appear after the second or third decade of life,

Corresponding author: Dra. Juliana Boaventura Avelar. e-mail: jubavelar@hotmail.com

Received 17 May 2017

Accepted 4 January 2017 and previous studies have shown that $80 \%$ of children with subclinical infection present ocular sequelae at some point in their lives. Therefore, a child that is asymptomatic at birth is not necessarily indicative of a better prognosis ${ }^{2,10,11}$.

Given that one of the main mechanisms of dissemination is through the ingestion of the parasite at its various developmental stages, infection can occur through the ingestion of $T$. gondii oocysts or cysts. Toxoplasmosis can be considered a foodborne disease, with the exception of congenital infection. One should be aware of the biological cycle of the parasite in order to study the factors for exposure to $T$. gondii, i.e., regarding the possible means of ingestion of oocysts present in the environment, or of tissue cysts in contaminated meat ${ }^{12}$.

Habits, behaviors, characteristics, and procedures that cause this contamination are considered risk factors ${ }^{13,14}$. However, the relationship between human and parasite may remain harmless if appropriate prophylactic measures are taken. Therefore, this paper proposes to identify the risk factors for toxoplasmosis in postpartum women treated in the public healthcare system [Sistema Único de Saúde (SUS)] in the municipality of Goiânia, State of Goiás, Brazil. 


\section{METHODS}

This is a cross-sectional analysis of toxoplasmosis among postpartum women chronically infected by $T$. gondii, aiming to assess the risk factors for this infection.

\section{Ethical considerations}

The research project was approved by the Ethics Committee of the Clinical Hospital [Hospital das Clínicas (HC)] of Universidade Federal de Goiás (UFG), under Protocol no. $142 / 2009$, in conformity with the ethical and legal aspects of research involving humans established by Resolution $466 / 12$ of the National Health Council ${ }^{15}$.

Two public maternity wards were chosen in Goiânia (16 $\left.40^{\circ} 49^{\prime \prime} \mathrm{S} 49^{\circ} 15^{\prime} 23^{\prime \prime} \mathrm{W}\right)$, namely, the maternity ward of the HC of UFG, which is a reference hospital for high-risk pregnancies and the Maternidade Nossa Senhora de Lourdes (MNSL), a reference for low-risk, or standard pregnancies. All the participants of this study were treated in the public health network of the municipality of Goiânia, Goiás between February 2010, and July 2011.

The parameters for estimating sample size were: prevalence of $70 \%$, level of reliability (type I error) of $5 \%$ and level of accuracy of $0.6 \%$. Therefore, a minimum of 224 women would be required. The pregnant women were selected during their admission to the maternity wards. So as not to interfere in the routine health care of the service, postpartum women were invited to participate in the study after giving birth in one of these maternity wards. Signed informed consent was obtained, and interviews were conducted individually after the patient had undergone her medical procedure or nursing care, thus ensuring the participant's privacy.

The eligibility criteria for participation in the study were: a postpartum woman and agreement to participate by signing a free, prior and informed consent (FPIC) form.

Two hundred and seventy-two postpartum women were invited to be part of the study, 32 of whom did not agree to participate and 11 cases were excluded due to inconsistencies in the serological results, thus there was a loss of $43(15.9 \%)$ cases. The probabilistic sample consisted of 229 puerperal women, of which 121 were from the HC-UFG and 108 from the MNSL, both from the urban area of the City of Goiânia, Goiás. Of the 229 puerperal women, 204 were $T$. gondii immunoglobulin G (IgG) positive, while 25 were negative.

After the interview, a $5 \mathrm{ml}$ aliquot of venous blood was collected from each patient for a $T$. gondii IgG and IgM enzymelinked immunosorbent assay (ELISA). A further exclusion criterion was when a pregnant woman did not consent to give a blood sample, thus excluding her as a participant.

The ELISAs (Interteck Katal ${ }^{\circledR}$, São Paulo, Brazil) were performed to confirm the presence or absence of anti-T. gondii antibodies in the 229 blood samples. Immunoglobulin M (IgM) sensitivity was $99.4 \%$, with $99.9 \%$ specificity, while $\operatorname{IgG}$ sensitivity was $98.3 \%$ with $99.2 \%$ specificity.

Any titer above the manufacturer-recommended cutoff point was considered positive for either IgG or IgM (dependent variable). For the purpose of analysis, the variables obtained from the questionnaires and medical records were grouped as follows: Independent variables, which included 1) sociodemographic characteristics (ethnicity, level of education, marital status, age, family income, place of residence, work, number of pregnancies); 2) Dietary habits (consumption of meat, raw or undercooked meat, filtered or mineral water); 3) behavioral habits (canine or feline pet ownership).

Statistical analyses were performed using BioEstat ${ }^{\circledR}$ v.5.3 software (Instituto Mamirauá, Tefé, Brasil). The database was built using Epi Info ${ }^{\text {TM }}$ 3.3.2 (CDC, Atlanta, GA, USA), and the variables were subjected to frequency distribution to build the profile of the study participants. The toxoplasmosis prevalence rate in the sample under study was estimated by dividing the number of ELISA-positive cases by the total number of exams, with a $95 \%$ confidence interval $(95 \% \mathrm{CI})^{16,17}$.

The independent effect among the selected variables was determined using ELISA positivity, which was determined using a univariate logistic model to estimate the odds ratio (OR) with a 95\% CI among the subgroups formed from each variable ${ }^{18}$.

\section{RESULTS}

Of the eligible sample $(n=229), 204$ or $89 \%(95 \%$ CI: $87.37-94.37$ ) were $\mathrm{IgG}$ positive for toxoplasmosis, while 25 or $10.9 \%$ (95\% CI: 8.37-14.37) were seronegative, and therefore constituted the control group. No pregnant women were found to have IgM class antibodies against $T$. gondii. Thus, indicating the high prevalence rate of $T$. gondii infection in Goiânia, Goiás ${ }^{10}$.

The sociodemographic characteristics that were significantly associated with the risk for toxoplasmosis $(\mathrm{p}<0.05)$ in this group were: being 30 years or older, living in Goiânia for one year or more, and having less than 8 years of schooling, as shown in Table 1.

The characteristics related to eating raw and undercooked meat, drinking habits, and clinical and behavioral aspects were not found to be risk factors associated with a positive test for toxoplasmosis $(\mathrm{p}<0.05)$, which are highlighted in bold font in Table 2.

\section{DIsCusSION}

Knowledge about the sociodemographic profile of the population of women of childbearing age is very important for the formulation of primary and secondary health care actions to deal with toxoplasmosis. This evaluation is important in Brazil, which is a continental country with clear ethnic and social differences; these factors must be considered by the public health management organizations.

The main risk factors for this infection described in the literature include: age, educational level, and eating habits, as demonstrated in this study. We found that there was a correlation between toxoplasmosis seroprevalence and age, which was similar to findings from most surveys that included this type of analysis, not only in postpartum women and those of reproductive age, but also in the general population ${ }^{19-21}$. Positive seroprevalence is more relevant after 31 years of age, 


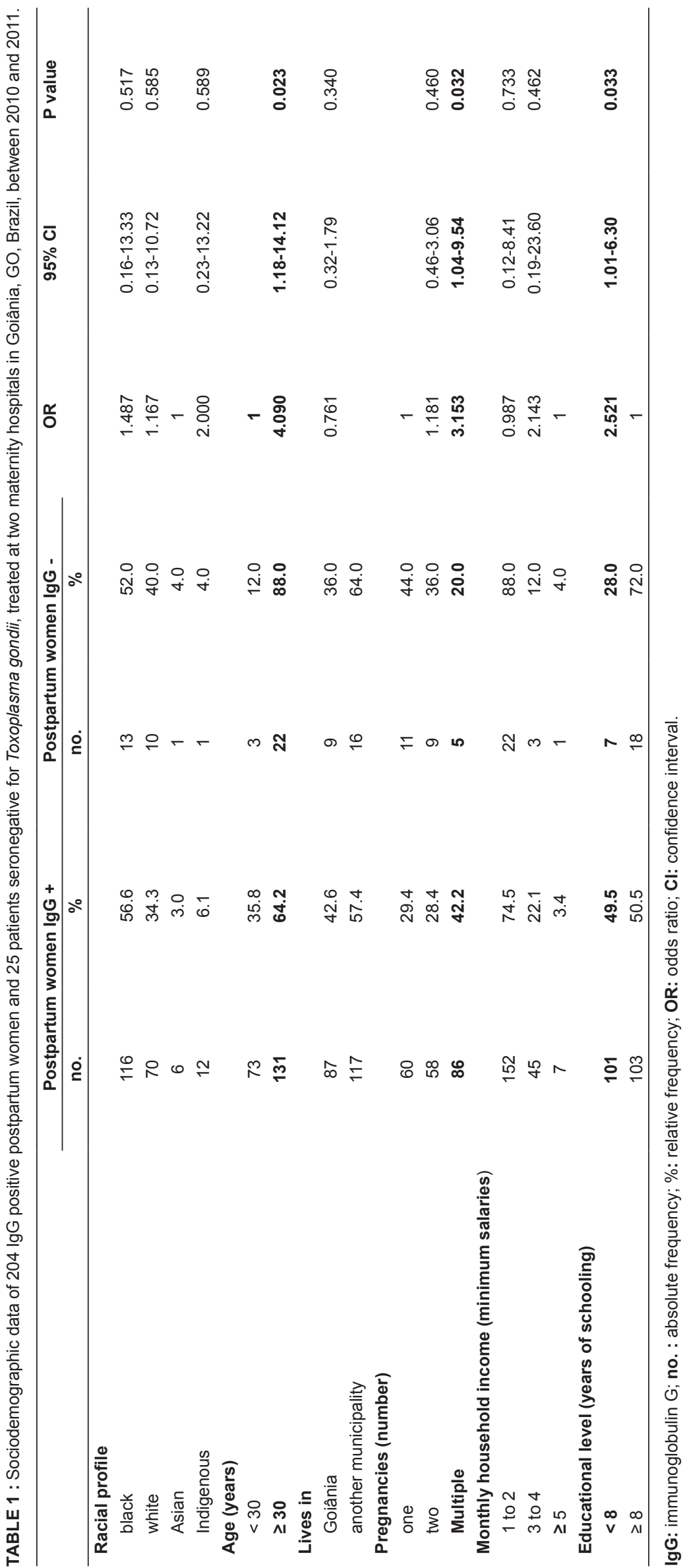

according to the literature, which was confirmed in this study. Seroprevalence in those older than 30 years represented the majority of infections in our study $(64.2 \%)$, and in other national studies $(59,8 \%$, $45 \%, 74,5 \%$ and $68,7 \%$, respectively $)^{20,22-24}$. The seroprevalence of $T$. gondii is higher in older people than younger people, due to the longer exposure time, so they are more susceptible to contamination by the different infective forms of $T$. gondii ${ }^{25,26}$.

Although these results were largely nonsignificant, there remains an important correlate of infection with $T$. gondii, due to the high seroprevalence in the population of this municipality $2,10,11,27-29$. Since the 1970s, the seroprevalence of $T$. gondii in Goiânia has resulted in $54.76 \%$ of this population developing toxoplasmosis ${ }^{30}$. Additionally, despite all the improvements in health programs, after four decades, seroprevalence remains high $^{31}$.

The educational level of postpartum women appeared to be a significant risk factor for this parasitic infection in women with fewer than eight years of schooling (OR: 2.521). This inverse association supports the hypothesis that low educational levels increase the risk of exposure, due to failure to adopt better food-related hygiene measures, and this in turn underscores the importance of investments aimed at access to quality education as a means to promote public health ${ }^{24,27}$.

The relationship between behavioral, and eating habits, and positivity for toxoplasmosis, as well as current or past ownership of dogs, and consumption of raw or undercooked meat, were not identified as risk factors. A factor that differs from other studies was the fact that no relation was found between owning dogs or cats and $T$. gondii contamination. Cats can disseminate oocysts in the environment, while dogs can act as mechanical vectors by assisting in the transmission of $T$. gondii oocysts adhered to their hair ${ }^{11,32,33}$.

Another factor known to be associated with toxoplasma infection is living with cats, which was not recorded in this survey. National and international epidemiological studies are not consistent concerning the association between $T$. gondii infection, and living with cats. The results of this study are in agreement with those reported in Ireland ${ }^{34}$ and Recife ${ }^{35}$, where this association was also not significant. However, they differ from findings reported in Goiânia ${ }^{11}$, Tocantins ${ }^{14}$ and in the region of the Upper Uruguay River ${ }^{23}$, where a significant association $(\mathrm{p}<0.05)$ was found between living with cats, and seropositivity in pregnant women.

As for studies carried out abroad, the findings of this study are comparable to those reported in 
Avelar JB - et al: - Epidemiology of postpartum toxoplasmosis

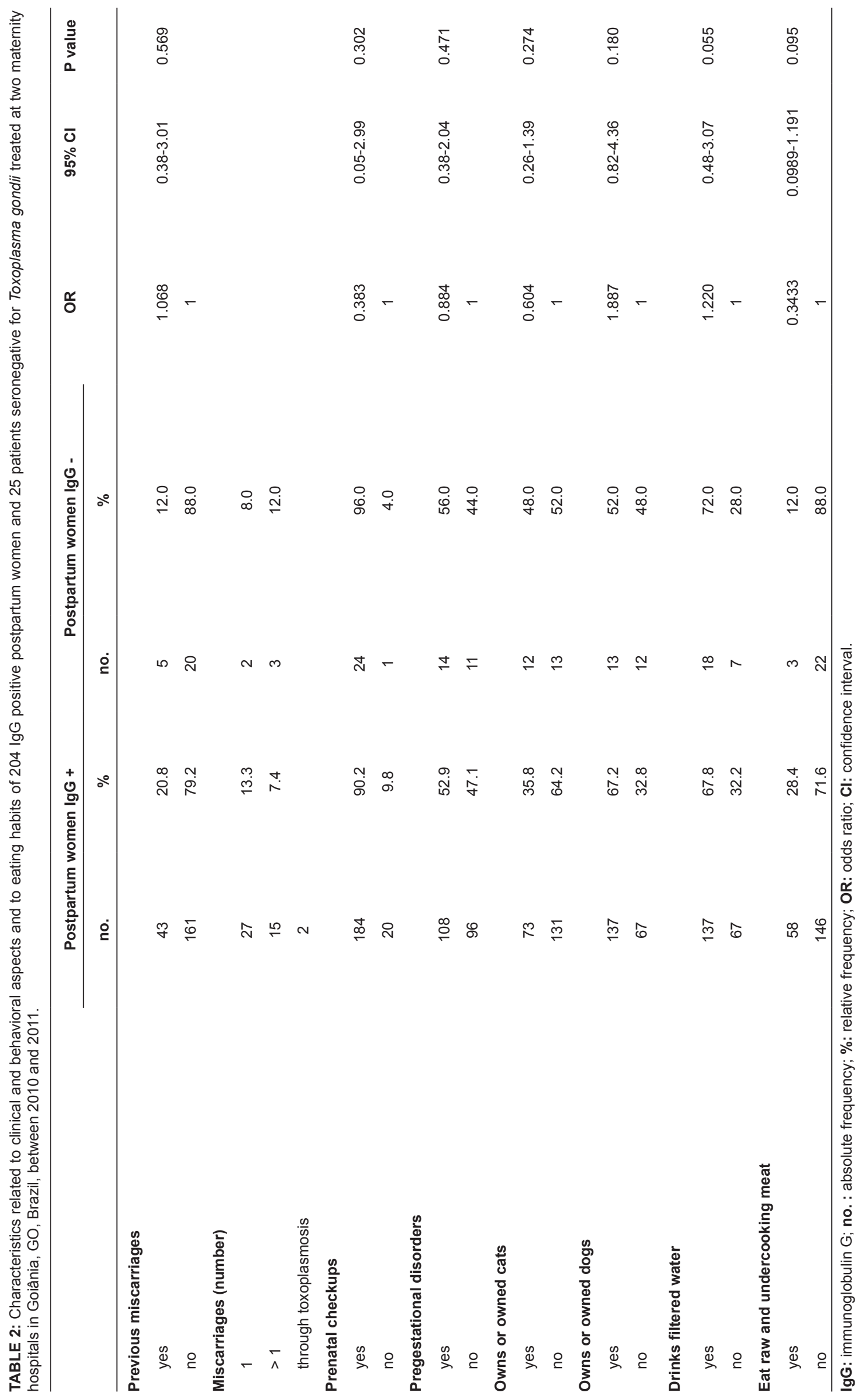

60 
Europe $^{36}$, Venezuela ${ }^{37}$ and the United States ${ }^{1}$, which did not reveal a correlation between seropositivity, and living with cats. According to the authors, the possibility of a person becoming infected by touching cats is negligible or nonexistent. There may be a risk of infection only through direct contact with the feces of cats that are eliminating oocysts after their initial first infection. Moreover, cat feces must be in the environment for at least 24 hours for the oocyst to sporulate and become infectious. Collecting newly deposited feces and discarding them in the toilet does not pose a risk for infection, nor does daily cleaning of the cat's litter box. Moreover, pets kept in confinement, which do not hunt and are fed with cooked meat and processed cat food, are not at risk of becoming infected ${ }^{1,36,37}$. However, a recent study in Ethiopia found an association between contact with cats and $T$. gondii infection in pregnant women, and also the contact of this group of women with soil ${ }^{38}$.

Most published studies have found a direct correlation between the consumption of raw food and toxoplasma infection; however, this correlation was not found in this study. In animal-based foods, T. gondii has been found encysted in pig, sheep, and goat tissues more often than in the tissues of other domestic animals. However, viable $T$. gondii is rarely found in beef, and to date, the importance of beef in the epidemiology of $T$. gondii infection is uncertain ${ }^{16,39}$. A study in cattle in the State of Goiás showed that $100 \%$ of the animals evaluated had positive serology for $T$. gondii ${ }^{40}$.

In a multicenter European study, the main risk factor for infection among pregnant women was found to be the consumption of raw or undercooked meat in $30 \%$ to $63 \%$ of cases $^{36}$. The consumption of these foods at least once a month increased the risk of $T$. gondii infection three-fold ${ }^{41}$. In a study conducted in the state of Tocantins, Brazil, involving 338 pregnant women, handling meat was found to be associated with $T$. gondii infection ${ }^{14}$.

Knowledge about risk factors and life habits that favor T. gondii infection is important in planning educational programs aimed at reducing the incidence of toxoplasmosis during pregnancy. The best measures to prevent toxoplasmosis are primary prevention measures, which are basically characterized by education and public health programs recommended to pregnant women through campaigns, lectures, pamphlets and guidance by health care teams, aimed at avoiding contact with potentially harmful materials contaminated through contact with dogs and cats, and avoiding the consumption of raw or undercooked meat. The use of gloves when handling soil is also emphasized. A $63 \%$ reduction in the first gestational infection can be achieved by following these recommendations during pregnancy ${ }^{11}$.

This study revealed some risk factors for $T$. gondii infection in a population of postpartum women. It is possible that a greater number of controls in the study could demonstrate other risk factors for T. gondii infection; this population would include women that are under-schooled and over 30 years old.

Knowledge of risk factors for toxoplasmosis is important for planning and designing control measures in primary care. Such measures should be adopted to minimize failures in the diagnosis of congenital transmission diseases as well as the early detection of infected children. A limitation found in the study refers to the fact that women were approached immediately after delivery of their infant, or within 24 hours thereafter, as authorization was required for the collection of blood from their respective newborns. These authorizations were not always easily consented, since the child was not born diagnosed with any congenital disease, and many mothers were apprehensive in authorizing the collection of blood in their children, thus demonstrating the lack of knowledge about infectious diseases and congenital transmission thereof.

Public health services need to be better organized to provide antenatal care throughout pregnancy, as well as the minimum routine examinations recommended by the Ministry of Health, to ensure timely and proper treatment of infected patients.

\section{Acknowledgements}

We would like to thank to board directors from Maternidade Nossa Senhora de Lourdes (MNSL) and the board directors from Hospital das Clinicas/ Universidade Federal de Goiás (HC/UFG), including all the women who collaborated with this study.

\section{Conflict of interest}

The authors declare that there are no conflicts of interest.

\section{Financial support}

The authors gratefully acknowledge the Brazilian research funding agencies: National Council for Scientific and Technological Development [Conselho Nacional de Desenvolvimento Científico e Tecnológico (CNPq)] and Goiás State Research Foundation [Fundação de Amparo à Pesquisa do Estado de Goiás (FAPEG)] for their financial support of this research.

\section{REFERENCES}

1. Jones JL, Kruszon-Moran D, Rivera HN, Price C, Wilkins PP. Toxoplasma gondii seroprevalence in the United States 2009-2010 and comparison with the past two decades. Am J Trop Med Hyg. 2014;90(6):1135-9.

2. Spalding SM, Amendoeira MRR, Ribeiro LC, Silveira C, Garcia AP, Camilo-Coura L. Estudo prospectivo de gestantes e seus bebês com risco de transmissão de toxoplasmose congênita em município do Rio Grande do Sul. Rev Soc Bras Med Trop. 2003;36(4):483-91.

3. Câmara JT, Silva MG, Castro AM. Prevalência de toxoplasmose em gestantes atendidas em dois centros de referência em uma cidade do nordeste, Brasil. Rev Bras Ginecol Obstet. 2015;37(2):64-70.

4. Avelar JB, Rezende HHA, Storchilo HR, Candido RR, Amaral WN, Avelino MM. Reativação da toxoplasmose durante o oitavo mês de gestação. Renome. 2015;4(1):57-69.

5. Andrade GM, Santos DV, Carellos EV, Romanelli RM, Vitor RW, Carneiro AC. Congenital toxoplasmosis from a chronically infected woman with reactivation of retinochorioiditis during pregnancy. Rev Soc Bras Ped. 2010;86(1):85-8.

6. Bachmeyer C, Mouchnino G, Thulliez P, Blum L. Congenital toxoplasmosis from an HIV-infected woman as a result of reactivation. J Infect. 2006;52(2):55-7.

7. Elbez-Rubinstein A, Ajzenberg D, Dardé ML, Cohen R, Dumètre A, Yera H. Congenital toxoplasmosis and reinfection during 
pregnancy: case report, strain characterization, experimental model of reinfection, and review. J Infect Dis. 2009;199(2):280-5.

8. Yadav RK, Maity S, Saha S. A review on TORCH: groups of congenital infection during pregnancy. J Sci In Res. 2014;3(2):25864.

9. Moura FL, Amendoeira MRR, Bastos OMP, Mattos DPBG, Fonseca ABM, Nicolau JL. Prevalence and risk factors for Toxoplasma gondii infection among pregnant and postpartum women attended at public healthcare facilities in the city of Niterói, state of Rio de Janeiro, Brazil. Rev Soc Bras Med Trop. 2013;46(2):200-7.

10. Lebech M, Joynson DHM, Seitz HM, Thulliez P, Gilbert RE, Dutton GN, et al. Classification system and case definitions of Toxoplasma gondii infection in immunocompetent pregnant women and their congenitally infected offspring. Eur J Clin Microbiol Infect Dis. 1996;15(10):799-805.

11. Figueiró-Filho EA, Lopes AHA, Senefonte FRA, Souza-JuniorVG, Botelho CA, Figueiredo MS, et al. Toxoplasmose aguda: estudo da frequência, taxa de trans- missão vertical e relação entre os testes diagnósticos materno- fetais em gestantes em estado da Região Centro-Oeste do Brasil. Rev Bras Ginecol Obstet. 2005;27(8):442-9.

12. Dubey J. Toxoplasmosis of animals and humans. $2^{\text {nd }}$ edition. New York: CRC Press; 2010. 21p.

13. Carellos EVM, Andrade GMQ, Vasconcelos-Santos DV, Januário $\mathrm{JN}$, Romanelli RMC, Abreu MNS. et al. Adverse socioeconomic conditions and oocyst-related factors are associated with congenital toxoplasmosis in a population-based study in Minas Gerais, Brazil. PLoS One. 2014;9(2):e88588.

14. Rocha EM, Lopes CWG, Ramos RAN, Alves LC. Risk factors for Toxoplasma gondii infection among pregnant women from the state of Tocantins, northern Brazil. Rev Soc Bras Med Trop. 2015;46(6):773-5.

15. Ministério da Saúde (MS). Diretrizes e normas regulamentares da pesquisa envolvendo seres humanos. Resolução n. ${ }^{\circ} 466$ de 12 de dezembro de 2012. Conselho Nacional de Saúde. Brasília: MS; 2013.

16. Andrade ALSS. Métodos de investigação epidemiológica em doenças transmissíveis. $2^{\text {nd }}$ edition Goiânia: I; 1998. 6p.

17. Bonita R, Beaglehole R, Kjellström T. Epidemiologia básica. $2^{\text {nd }}$ edition. Santos: Livraria Santos Editora Com. Imp. Ltda; 2010. 175p.

18. Oliveira Filho PF. Epidemiologia e bioestaística: fundamentos para leitura crítica. $1^{\text {st }}$ edition. Rio de Janiero: Rubio; 2015. 248 p.

19. Oliveira-Bahia L, Abreu A, Azevedo-Silva J, Oréfice F. Toxoplasmosis in southeastern Brazil: an alarming situation of highly endemicacquired and congenital infection. Int J Parasitol. 2001;31:115-44.

20. Varella IS, Wagner MB, Darela AC, Nunes LM, Müller RW. Prevalência de soropositividade para toxoplasmose em gestantes. J Pediatr. 2003;79(1):69-74.

21. Ertug S, Okyay P, Turkmen M, Yuksel H. Seroprevalence and risk factors for Toxoplasma infection among pregnant women in Aydin province, Turkey. BMC Public Health. 2005;5:66-76.

22. Nascimento TL, Pacheco CM, Souza FF. Prevalência de Toxoplasma gondii em gestantes atendidas pelo Sistema Único de Saúde. Ciênc Saúde Coletiva. 2017;10(2):96-101.

23. Spalding S, Amendoeira M, Ribeiro L, Silveira C, Garcia AP, Camillo-Coura L. Estudo prospectivo de gestantes e seus bebês com risco de transmissão de toxoplasmose congênita em município do Rio Grande do Sul - Brasil. Rev Soc Bras Med Trop. 2003;36(4):483-91.

24. Silva MG, Câmara JT, Vinaud MC, Castro AM. Epidemiological factors associated with seropositivity for toxoplasmosis in pregnant women from Gurupi, State of Tocantins, Brazil. Rev Soc Bras Med Trop. 2014;47(4):469-75.

25. Strhársky J, Klement C, Hrub F. Seroprevalence of Toxoplasma gondii Antibodies in the Slovak Republic. Folia Microbiol. 2009; 54(6):553-8.

26. Studenicŏva C, Bencăiova G, Holkova R. Seroprevalence of Toxoplasma gondii antibodies in a healthy population from Slovakia. Eur J Intern Med 2006;17(7):470-3.

27. Avelino M, Campos-júnior D, Parada J, Castro AM. Risk factors for Toxoplasma gondii infection in women of childbearing age. Braz J Infect Dis. 2004;8(2):164-74.

28. Avelino M, Amaral W. Toxoplasmose e gravidez. In: Avelino M, Amaral W, editors. Transmissão vertical, infecções congênitas. $1^{\text {st }}$ edition. Goiânia: Contato Comunicações; 2008. p. 57-112.

29. Lima RCM, Amaral WN, Costa Jr AO Gonçaves FT, Tocchio ML, Candido RL, et al. Relação entre más-formações e óbitos fetais em decorrência de toxoplasmose congênita tratadas em uma clínica particular de Goiânia-GO. Ensaios Cienc Cienc Biol Agrar Saúde. 2011;15(4):53-63.

30. Fernandes WJ, Barbosa W. Toxoplasmose em Goiás. Comparação dos resultados da reação de Sabin-Fetdman em investigação clínica e epidemiológica. Rev Soc Bras Med Trop. 1972;1:29-38.

31. Barbaresco AA, Costa TL, Avelar JB, Rodrigues IMX, Amaral NA, Castro AM. Infecções de transmissão vertical em material abortivo e sangue com ênfase em Toxoplasmose gondii. Rev Bras Gineco Obstet. 2014;36(1):17-22.

32. Etheredge G, Michael G, Muehlenbein M, Frenkel K. The roles of cats and dogs in the transmission of Toxoplasma infection in Kuna and Embera children in eastern Panama. Rev Panam Salud Publica. 2004;16(3):176-86.

33. Dubey JP. A review of toxoplasmosis in wild birds. Vet Parasitol. 2002;106(2):121-53.

34. Ferguson W, Mayne PD, Cafferkey M, Butler K. Lack of awareness of risk factors for primary toxoplasmosis in pregnancy. Ir J Med Sci. 2011;180(4):807-11.

35. Porto AMF, Amorim MMR, Coelho ICN. Perfil sorológico para toxoplasmose em gestantes atendidas em maternidade. Rev Assoc Med Bras. 2008;54(3):242-8.

36. Cook A, Gilbert R, Buffolano W, Zufferey J, Petersen E, Jenum PA. Sources of Toxoplasma infection in pregnant women: European multicentre case-control study. European research network on congenital toxoplasmosis. BMJ. 2000;321(7254):142-7.

37. Bracho L, Sanoja C, Granadillo A. Seroepidemiología de la infección por Toxoplasma gondii en embarazadas. Kasmera. 2001;29(2):45-60.

38. Abamecha F, Awel H. Seroprevalence and risk factors of Toxoplasma gondii infection in pregnant women following antenatal care at Mizan Aman General Hospital, Bench Maji Zone (BMZ), Ethiopia. BMC Infect Dis. 2016;16(1):460-8.

39. Dubey J. Strategies to reduce transmission of Toxoplasma gondii to animals and humans. Vet Parasitol. 1996;64(1-2):65-70.

40. Santin API, Juliano RS, SIlva AC, Oliveira VSF, Junqueria-Kipnis AP, Brito WMED, Fioravanti MCS. Soroepidemiologia de Neospora caninum e Toxoplasma gondii em bovinos da raça curraleiro. Cien Anim Bras. 2017:18:1-8.

41. Buffolano W, Gilbert R, Holland F, Fratta D, Palumbo F, Ades AE. Risk factors for recent Toxoplasma infection in pregnant women in Naples. [Epidemiol Infect. 1996;116(3):347-51. 